\title{
PROBLEMS OF NEUROPSYCHOLOGY AS A METHODOLOGICAL APPROACH TO THE HIGHER MENTAL FUNCTIONS STUDIES
}

\begin{abstract}
Дроздова І. В., Нагачевська О. О., Дроздов О. Л., Ломаковська А. В. Проблеми нейропсихології як методологіного підходу до вивчення вищих психічних функцій

У статті проаналізовано проблеми нейропсихології як методології вивчення вищих психічних функцій людини. Детально розглянуто відмінності вітчизняної та зарубіжних наукових шкіл, представлено основні класи понять нейропсихології. Теорія системної динамічної локалізації вищих психічних функцій є центральним розділом учення вітчизняної нейропсихології. Вона дозволяє не лише пояснити відмінності клінічної феноменології, але й передбачає можливість появи нових фактів і досліджень, що нині є основю для вивчення складної проблеми мозкового субстрату психічних процесів.
\end{abstract}

Ключові слова: нейропсихологія, методологія, вищі психічні функції, огляд

Дроздова И. В., Нагачевская Е. А., Дроздов А. Л., Ломаковская А. В. Проблемы нейропсихологии как методологического подхода к изучению высших психических функций

В статье дан анализ проблемы нейропсихологии как методологии изучения высших психических функций человека. Детально рассмотрены отличия отечественной и зарубежных научных школ, представлены основные классы понятий нейропсихологии. Теория системной динамической локализации высших психических функций представляет центральный раздел в понятиях отечественной нейропсихологии. Она позволяет не только объяснять различную клиническую феноменологию, но и предусматривает возможность появления новых фактов и исследований, что сегодня является основой для изучения сложной проблемы мозгового субстрата психических процессов.

Ключевые слова: нейропсихология, методология, высшие психические функции, обзор

Drozdova I.V., Nagachevska O.O., Drozdov A. L., Lomakovska H. V. Problems of neuropsychology as a methodological approach to the higher mental functions studies

The paper researches the problem of neuropsychology as a methodology for studying the higher mental human functions. The differences between domestic and foreign scientific schools are examined in detail, the main classes of concepts of neuropsychology are presented. The theory of systemic dynamic localization of higher mental human functions represents the main section in the concepts of domestic neuropsychology. It allows not only to explain the various clinical phenomenology, but also provides for the possible emergency of new facts and investigations, which is the basis for contemporary research of the complex issue of the brain substrate of mental processes.

Key words: neuropsychology, methodology, higher mental human functions, review

Issue Statement. The theory of systematic dynamic localization of higher psychic functions in national neuropsychology was formed on the basis of the general psychological theory provisions developed by L.S. Vygotsky and his adherents: A.M. Leontiev, A.R. Luria, P. Ya. Galperin, A.V. Zaporozhets, D.B. Elkonin and other psychologists. The main provisions of this theory are the 
components of the theoretical conceptual system of neuropsychology, which established the general psychological "framework". The success of national neuropsychology is largely caused by its direct connection with general psychological theory and the application of adequate general psychological models for the pathologies analysis. There are two classes of concepts in the conceptual framework of neuropsychology. The first one comprises concepts common for neuropsychology and general psychology; the second contains the actual neuropsychological concepts determined by the specifics of its subject, object and methods of research.

The concepts of the first class are: higher mental function, mental activity, psychological system, mental process, language mediation, meaning, personal content, psychological instrument, image, sign, action, operation, interiorization and more [38]. The content of these concepts is presented in a number of manuals and monographs on general psychological problems $[10 ; 14 ; 17$; $21 ; 25]$.

The second class implicates proper neuropsychological concepts reflecting the application of general psychological theory to neuropsychology which is the specific branch of knowledge, where the object is the reseach of the brain organization of mental processes, emotional states and personality material and pathology and, above all, material and local brain lesions. Together, these concepts make up a certain system of knowledge, or theory of united positions, explain the patterns of disorders and the restoration of higher mental functions at local brain lesions and substantiate the idea of their brain organization.

Scientific research review. This theory is able, on the one hand, to explain the diverse clinical phenomenology of mental function disorders, and on the other - satisfactorily predict new facts and patterns. The general psychological basis of this theory is the position of the systemic structure of higher mental functions and their hierarchical brain structure. The concept of "higher mental functions" is central for neuropsychology and was introduced into general psychology and neuropsychology by L. S. Vygotsky, and then elaborated in detail by A. R. Luria and other scientists $[10 ; 11 ; 15 ; 16]$. In neuropsychology, as in general psychology, higher mental functions mean complex forms of conscious mental activity, performed on the basis of appropriate motives, and regulated by a specific purpose and programs and are subjected to all the patterns of mental activity.

In addition to higher mental functions L. S. Vygotsky also distinguished some elementary mental functions. One of the criteria for their selection was the notion that higher mental functions arise antemortem and are based on elementary innate functions. Later, L. S. Vygotsky and other authors revealed that elementary mental functions also undergo qualitative changes in the process of social development $[10 ; 11]$.

As it was stated by A. R. Luria, higher mental functions have three main characteristics: they are formed in a lifetime under the influence of social factors; mediated by their psychological structure (mainly through the language system); arbitrary by way of implementation $[15 ; 16]$. The ideas about higher mental functions as in socially determined mental entities, or conscious forms of mental activity are based on theoretical and methodological provisions of general psychology about the socio-historical origin of the human psyche and the determinative role of labour activity in the formation of his consciousness $[15 ; 16]$. Social influences determine the ways of formation of higher mental functions, and thus their psychological structure. Higher psychic functions are mediated by various "psychological tools" so called systems that are the products of the contiinued socio-historical development. Among the "psychological instruments" language plays a crucial role. Therefore, linguistic mediation of higher psychic functions is the most versatile method of their formation.

The purpose of the work is to perform a theoretical analysis of recent researches of higher mental functions in terms of neuropsychology as a science.

Outline of the substantive inputs and research findings. Higher psychic functions are complex systemic formations that are qualitatively different from other psychic phenomena. The main characteristics of higher psychic functions are mediocrity, awareness, arbitrariness which are defined as systemic qualities characterizing these functions as "psychological systems" created by superimposing new formations over the old ones while preserving the latter as subordinate structures in the midst of a new whole $[10 ; 11]$. Higher psychic functions as systems are 
characterized with great plasticity, interchangeability of input components. They have invariable (invariant) initial tasks (conscious aim or activity program) and the final outcome; the means by which these tasks are realized are highly variable and different at different stages in different ways and methods of forming the function $[37 ; 38]$.

The pattern of higher mental functions formation is their initial existence as a form of interaction between people (i.e., as an interpsychological process), and only later - as a completely internal (intrapsychological) process. Simultaneously with higher psychic functions formation the transformation of external means of function exercising into internal, psychological (internalization) is performed. In the process of development, higher mental functions are gradually "curtailed", automated. On the first stages of formation the higher mental functions are a detailed form of subject activity, which relies on relatively elementary sensory and motor processes; then these actions and processes are "curtailed" acquiring the character of automated mental actions [12; 13]. At the same time the psychological structure of higher mental functions is changing.

The definition of higher mental functions as complex psychological systems was supplemented by A. R. Luria's conception of them as functional systems. In neuropsychology the functional system is determined as the morphophysiological basis of higher mental functions which ensures their performance (i.e., a set of different brain structures in which certain physiological processes take place). Defining higher mental functions as functional systems he stated that the peculiarity of such functional systems is their hierarchical composition, which is a whole set of afferent and efferent components or units $[15 ; 16]$. Thus, higher mental functions, or complex forms of conscious mental activity, systemic in their psychological structure, have a complex morphophysiological basis in the form of multicomponent functional systems. These provisions are principal for the theory of systematic dynamic localization of higher mental functions - the theoretical basis of modern domestic neuropsychology [37;38].

The second class of neuropsychological concepts can be attributed to the following. A neuropsychological symptom is a disturbance of mental function resulting from local brain damage (or a result of the other pathological causes leading to local changes of brain function). Primary neuropsychological symptoms are mental function disabilities, directly related to the damage (loss) of a certain neuropsychological factor. Secondary neuropsychological symptoms are disturbances of mental functions that arise as systemic consequences of primary neuropsychological symptoms according to the laws of their systemic relationships. Neuropsychological syndrome is a natural combination of neuropsychological symptoms caused by the damage (loss) of a certain factor (or several factors). A neuropsychological factor is a structural and functional unit of the brain that is characterized by a certain principle of physiological activity, the violation of which leads to the appearance of a neuropsychological syndrome [37;38].

Syndromic analysis is determined as the analysis of neuropsychological syndromes in order to identify common factors that explain the origin of various neuropsychological symptoms; research of the qualitative specificity of disorders of different mental functions associated with the damage (loss) of a certain factor; qualitative qualification of neuropsychological symptoms (this may be synonymous with factor analysis). Neuropsychological diagnosis is the study of patients with local brain lesions using clinical neuropsychological methods to determine the location of brain lesions (topical diagnosis). Functional system is a morphophysiological concept borrowed from the P.K. Anokhin's functional systems conception to explain the brain mechanisms of higher mental functions; a set of afferent and efferent units integrated into the system to achieve the final result. Functional systems that underlie human mental conscious activity are more complex (complex links and hierarchical organization) than functional systems that underlie physiological functions and even animal behavioral acts. Higher mental functions (gnostic, mystical, intellectual) different in content are provided with qualitatively different functional systems [2;3].

Brain mechanisms of higher mental functions (morphophysiological basis of mental function) are the set of morphological structures (zones, areas) in the cortex of large hemispheres and in subcortical formations in which certain physiological processes occur within a single functional system and which are necessary for this mental activity performance. Localization of higher mental function (brain organization of higher mental function) is the main concept of the theory of systematic dynamic localization of higher mental functions, which explains the connection of the 
brain with the psyche as a ratio of different links (aspects) of mental function with different neuropsychological factors (ie, the principles of those properties, or other brain structure - cortical or subcortical) [37; 38].

Brain structures polyfunctionality is the ability of brain structures (and, above all, associative zones of the cerebral cortex) to rebuild their functions under the influence of new afferent influences, resulting in an intrasystem and intersystem rearrangement of the affected functional systems. The norm of function is the concept on which neuropsychological diagnosis of disorders of higher mental functions is based; performance indicators (in psychological units of productivity, volume, speed) that characterize the average values in a given population. There are variants of "norms of function" associated with premorbid (sex, age, type of interhemispheric brain organization). Inter-hemispheric asymmetry of the brain is an inequality, a qualitative difference between the "contribution" that the left and right hemispheres of the brain make to every mental function; differences in cerebral organization of higher mental functions in the left and right hemispheres of the brain. Functional specificity of the large hemispheres - the specificity of information processing and brain organization of functions inherent in the left and right hemispheres of the brain and is determined by the integral hemispheric patterns. Inter-hemispheric interaction is a special mechanism for integrating the left and right hemispheres into a single integrative, fully functioning system, formed under the influence of both genetic and environmental factors [37; 38].

These concepts (as well as a number of others) are the main conceptual apparatus of the theory of systematic dynamic localization of higher mental human functions, developed in domestic neuropsychology L. S. Vygotsky and A. R. Luria $[10 ; 11 ; 15 ; 16]$. Creating a logically consistent theoretical conception that explains (taking into account various modern knowledge about the brain) the general principles of localization (or brain organization) of higher mental human functions, is an indisputable achievement of national neuropsychology, the most important contribution to modern ideas about the relationship between the brain and psyche [37;38].

The issue of localization of higher psychic functions or the problem of "brain and psyche" is one of the most significant issues of modern natural science. It belongs to interdisciplinary problems being developed in a number of disciplines: neuroanatomy, neurophysiology, neurology. Neuropsychology studies this problem from its standpoint examining the peculiarities of disorders of mental processes mainly in patients with local brain lesions. This problem, as we know, has always been the object of a fierce struggle between the followers of idealistic and materialistic views. Its relevance has not diminished to this day.

The theory of systematic dynamic localization of higher psychic functions was formed within the struggle between two main directions in solving the problem of "brain and psyche": narrow localization (or psychomorphological direction) and antilocalization (or the conception of brain equipotentiality). A detailed review of these scientific directions is given in monographs by A. R. Luria, as well as in the works of S. A. Sarkisov, I. N. Filimonov, V. M. Smirnova, O. S. Andijanova and several other authors. Criticism of these directions remains relevant even today [37; 38].

Narrow localization proceeds from the concept of psychic functions as inseparable components of a single psychic "ability" (to speak, write, read, compute), which must be fully correlated with certain morphological structures of the brain. The brain itself, and above all the cerebral cortex, is regarded by the mentioned scientific direction as a set of different "centers", each of which completely "manages" a certain mental capacity, and therefore the damage of the brain "center" leads to irreversible disturbance (or loss) of the corresponding ability. Localization of mental function ("ability") is understood as a direct correlation of mental and morphological (or direct "imposition" of mental on morphological), in connection with which this direction is called "psychomorphological". It should be noted that at present the pyshomorphological presentation is by no means compressed, especially in the minds of some doctors - clinicians who identify the localization of a symptom of disorders of mental function with the localization of this function. The most striking and consistent representatives of this trend at different times were neurologists who studied the effects of local brain lesions [citated with 37].

F. Halle's phrenological map and K. Kleist's localization map represent the logical conclusion of the ideas of narrow localization about the work of the cerebral cortex as a set of different "centers 
of psychic abilities". Another direction - antilocalization, is similar to narrow localization and in its relation to psychic functions as to irreducible psychic "abilities", and in its understanding of localization as a direct correlation of psychic and morphological. However, the brain, and above all the cortex, is interpreted in this direction as a homogeneous (equipotential) whole, equal and equivalent in relation to mental functions in all its departments. Mental functions ("abilities") are connected uniformly with the whole brain (and above all with the cortex of the large hemispheres), and any defeat of it leads to a proportional value of the pathological focus - the violation of all mental functions at the same time (or to the general deterioration of complex "symbolic functions The degree of impaired mental function does not depend on the localization of the lesion, but is determined only by the mass of the affected brain. The most striking representatives of this direction were some physiologists (P. Flurans, F. Golz, K. Lesley) and psychologists-ideas isty (Bergson) and other representatives Vyurtsburhskoi school) [37; 38]. Clinical observations of patients with local brain lesions seem to be supported by the facts of both of these directions: on the one hand, the defeat of individual parts of the brain (mainly the cerebral cortex) leads to various disorders of the mental processes, on the other - in local brain lesions are often observed. disorders that indicate the possibility of performing impaired functions in other parts of the brain. Neither one nor the other concept could explain these contradictions $[37 ; 38]$.

In the history of studying the problem of mental functions localization, there were (and still exist) other scietific directions. An eclectic concept, which has survived to the present time, combining psychomorphological and antilocalization views, is quite common. According to this concept (shared by researchers such as K. Monakov, K. Goldstein, G. Head, it is possible and necessary to localize (correlate with certain parts of the brain) only relative to elementary sensory and motor function. However, higher mental functions are connected evenly. with the whole brain (or with the central equipotential cortices [cit. 37].

The history of science acknowwledges and openly denies the problem of higher mental human functions localization, i.e. the very ability to connect the brain and psyche. These openly idealistic positions were held by such great physiologists as G. Helmholtz, C. Sherrington, E. Adrian, and R. Granit - the naturalists in science, but idealists in their philosophical outlook. In the late twentieth century, such views were held by the largest physiologist J. Eccles, who is known for his work on the study of synaptic transmission of impulses. In his monographs, "Brain and Psychic Experience", "Face to Face with Reality", J. Eccles emerges as a subjective idealist who regards the primary reality of consciousness as a "disease of science" [37;38].

The theory of systematic dynamic higher mental human functions localization was created in the fight against these directions, with the emphasis on the achievement of national psychology, on the one hand, and the materialistic physiology - on the other. In the national neuropsychology the concept of "function" was revised. Higher mental functions as psychological education began to be viewed from the standpoint of domestic psychological science as social in genesis (that is, lifelong, conditioned - socio-historical factors) tools (mainly speech); system building; conscious, dynamic in their organization (that is, different in psychological structure at different stages of ontogeny); arbitrary control method. Thus, the notion of undifferentiated psychic functions, as of further indistinguishable "abilities", has been replaced by modern notions of psychic functions as "psychological systems" having a complex psychological structure [18; 19].

Neuropsychology based on the achievements of national materialist physiology (the works of I. M. Sechenov, I. P. Pavlov, P. K. Anokhin, N. A. Bernstein, N. P. Bekhterev, E. H. Sokolova and other physiologists) considers psychic functions as formations having a complex reflexive basis, determined by external stimuli, or as complex forms of adaptive activity of the organism aimed at solving certain psychological problems. In the national neuropsychology the concept of "localization' is revised. Localization of mental functions is considered as a systemic process [16 19].

This means that mental function (as well as physiological, such as breathing) is related to the brain as a certain multicomponent system, different links of which are connected with the work of different brain structures. A. R. Luria believed that higher mental functions as complex functional systems could not be localized in narrow areas of the cerebral cortex or in isolated cell groups, but 
should rely on complex systems coexisting zones located in different, sometimes far-distant areas brain, each of which contributes to the implementation of mental processes [18].

Systematic localization of higher mental functions involves their multistage hierarchical multilevel brain organization. This inevitably follows from the complex multicomponent composition of functional systems on which higher psychic functions rely. One of the first researchers to point to the hierarchical principle of localization of higher mental functions was the domestic neurologist I. N. Filimonov, who called it the principle of "stepwise localization of functions' [31].

Localization of higher mental functions is also characterized by dynamism, variability. This principle derives from the basic properties of functional systems, mediating the higher mental functions: (plasticity, variability, interchangeability), which are part of their links and confirmed by clinical, physiological and anatomical data. Summarizing the results of many years of clinical observations, he formulated provisions on the functional ambiguity of brain structures, according to which many of them under certain conditions may be included in the performance of new functions [31]. This position was also defended by other researchers such as W. Penfield and G. Jasper. I. P. Pavlov also maintained the position on the functional ambiguity of brain structures. He distinguished in the cortex of the large hemispheres the "nuclear zones" of analyzers and the "scattered periphery' having plastic functions [24].

There is a great deal of physiological evidence for the validity of the idea of dynamism, the variability of brain organization of functions. These are primarily experimental studies of P.K. Anokhin and his students, who have shown that not only relatively complex behavioral acts, but also relatively simple physiological functions are provided by complex functional systems, where the replacement of some links by others is possible $[2 ; 3]$. In the writings of $\mathrm{N}$. A. Bernstein also find the further development of the idea of plasticity, dynamism of brain organization of functions. Studying the physiology of motions, N. A. Bernstein formulated a number of fundamental provisions about the construction of any function. These include the proposition that the motor system (which is any other function, including mental) is built on a "topological' rather than a "metric" principle, where invariant problems and the end result, but variant ways to solve the problem $[4 ; 5]$.

The principle of dynamic localization of higher human mental functions is based on modern anatomical findings. The researches findings of the Institute of Brain RAMS with the appliance of modern methods of research have established the variability under the influence of various influences of microsystems (or microassemblies), constituents of the basic macrosystems of the brain (projective, associative, integrative-starting and limbico-reticular). As the new provisions these data have been included to the conception of structural and systemic organization of brain functions developed by A.S. Adrianov [1].

The principle of dynamic localization of functions was first formulated by I.P. Pavlov and A. A. Ukhtomsky. He opposed the idea of localization of a function in a certain fixed "center". A. A. Ukhtomsky considering the mechanisms of dynamic localization of functions proved the great significance of the temporary performance of various elements that are the components of the "dynamic system" [24;29;30].

The ideas of I. P. Pavlov and A. A. Ukhtomsky about the dynamic localization (or brain organization) of functions have been confirmed in the works of N. P. Bekhterev [6; 7]. These studies, carried out by the method of recording the impulse neural activity of various deep structures of the brain, showed that any complex mental activity (memorizing words, solving a problem) is provided by the work of complex constellations of brain areas that make up the unit of a single system. Some of these links are "rigid", ie they are constantly involved in the exercise of mental function, others - "flexible", that is, they are included in the work only under certain conditions. The "flexible' links of the system are that mobile dynamic apparatus, through which the variability of the function is achieved.

In neuropsychology the principle of dynamic brain organization of higher psychic functions has been confirmed by various factual material and entered, as the most important, into the theory of systemic dynamic localization of functions. The above principles are common to the organization of both mental and physiological functions. That is why A.R. Luria used anatomical and 
physiological data obtained on animals to argue the position of the theory of localization of higher psychic functions [17 - 20].

However, higher human mental functions have not only greater complexity than the mental functions of animals, but even more so with physiological functions; they are characterized by qualitative differences - awareness, mediation: speech, arbitrary way of governing, the decisive importance of social factors in their formation. These qualitative differences of the higher mental functions of the person are manifested and features of their brain organization.

L. S. Vygotsky stated that comparative study of the same local brain lesions in childhood and adulthood reveals different disorders of higher mental functions and that these facts can only be interpreted as a consequence of differences in the brain organization of higher mental functions in children and adults $[10 ; 11]$. In modern neuropsychology, many data have been accumulated on the specificity of disorders of mental functions and neuropsychological syndromes in general in children compared with adults [23; 27], which confirm the validity of the ideas of L. S. Vygotsky and A. R. Luria regarding the chronogenic princes of localization of higher mental functions human. Formed life-long under the influence of social factors, the higher mental functions of a person change their psychological structure and, accordingly, their own brain organization. This is most clearly demonstrated by the example of language functions. If the adult literate (right-handed) cortical fields of the middle divisions of the left hemisphere play a leading role in the brain support of speech processes, then in children who do not possess literacy (up to 5-6 years), the language processes (comprehension of oral language and active language) are provided brain structures of the left and right hemispheres. The defeat of cortical "lingual zones" of the left hemisphere does not lead to expressive linguistic disorders in them. Thus, the principle of dynamic localization of functions in humans is also specified in the form of chronogenic localization, that is, in the change of brain organization of higher mental functions in ontogeny.

The human brain is characterized by distinguished hemispheric asymmetry, which can be considered as the most important fundamental pattern of his work. Although hemispheric asymmetry is not a unique feature of the human brain, as previously assumed, but also of the brain of animals, in humans it reaches maximum development [8;9]. There are not only quantitative but also qualitative differences between man and animals (even higher primates) in this respect. Interhemispheric asymmetry is manifested in both motor and sensory functions, but most clearly in higher psychic functions.

Interspecific differences in the cerebral organization of higher mental functions have been repeatedly described in clinical and neuropsychological literature as differences between symptoms and syndromes associated with lesions of the symmetric divisions of the large hemisphere. From the standpoint of the theory of systemic dynamic localization of functions, these differences can be designated as the principle of different localization (or brain organization) of all higher mental functions in the left and right hemispheres of the brain or the principle of lateral specialization of brain organization of mental functions. Studying the specific brain organization of each of the higher mental functions (in children and adults) is largely a matter of the future, as is the study of qualitative differences in the brain organization of the mental processes inherent in the left and right hemispheres. However, the current level of knowledge about the hemispheric asymmetry of the brain, achieved by neuropsychology and other sciences (physiology, anatomy, neurology), confirms the indisputable importance of this principle for understanding the general patterns of localization of higher mental functions in humans.

This principle may be true of the brain organization of certain mental functions in animals, as some authors write about it, but in humans it becomes universal in characterizing the brain organization of any mental function [8; 9]. And the importance of this principle in ontogeny, apparently, is growing, but this is not observed by all researchers, it is denied by V. M. Mosideta [37].

The human brain is characterized by the powerful development of the frontal lobes. In the area occupied by the bark of the frontal lobes, man surpasses all other representatives of the animal world. The "frontal brain" in humans continues to develop in ontogeny and finally forms only up to 12-14 years or even later. Being, first of all, a brain substrate of arbitrary complex forms of behavior, the "frontal brain" gradually, as it matures, becomes involved in the realization of all the 
higher mental functions of a person as one of the most important parts of functional systems. The importance of the anterior brain in the exercise of gnostic, mystical and intellectual functions is evidenced, in particular, by the EEG data obtained by the method of spatial synchronization of potentials in children of different age groups [33; 34], as well as the materials of comparative clinical observations of patients (children and adults). with the defeat of the frontal lobes of the brain [27]. The unconditional involvement of the frontal lobes in the brain organization of all higher mental functions (ie conscious, socially determined, speech-mediated, arbitrarily controlled forms of mental activity) has been proved by numerous studies of the effects of the defeat of the frontal lobes of the brain (especially the left frontal lobe). Crucial among these studies are the works of AR Luria and his students $[16 ; 19 ; 27 ; 38]$. From the standpoint of the theory of systemic dynamic localization of higher mental functions of a person, this pattern can be formulated as a principle of obligatory participation of the frontal prefrontal cortex in the cerebral supply of higher mental functions. This principle is specific to the brain organization of all conscious forms of human mental activity. Thus, according to the theory of systemic dynamic localization of higher mental functions of a person, every higher mental function is provided by the brain as a whole, but this whole consists of highly differentiated structures (systems, zones), each of which contributes to the realization of function $[16 ; 19 ; 27 ; 38]$.

Conclusions. Directly with brain structures (factors) it is necessary to associate not all mental function and even not its individual links, but those physiological processes which are carried out in these brain structures and provide realization of certain aspects (parameters) of function. Disruption of these physiological processes leads to the appearance of primary defects, as well as the associated secondary defects (primary and secondary neuropsychological symptoms), which are generally a natural combination of disorders of higher mental functions - a certain neuropsychological syndrome.

The theory of systematic dynamic localization of higher psychic functions, developed by L. S. Vygotsky and A. R. Luria, is the central section in the conceptual apparatus of domestic neuropsychology. It has great heuristic value, not only explaining diverse clinical phenomenology but also anticipating new facts and planning new research. At the same time, of course, this theory is only one of the first real steps in solving the complex problem of the brain substrate of mental processes, which is studied by almost all modern natural science.

\section{Література}

1. Адрианов О. С. Актуальные проблемы учения об организации функций мезга. Методологические аспекты науки о мозге. М.: Наука, 1983. 368 с.

2. Анохин П. К. Биология и нейрофизиология условного рефлекса. М.: Наука, 1968. 547 с.

3. Анохин П. К. Очерки физиологии функциональных систем. М.: Наука, 1975. 447 с.

4. Бернштейн Н. А. О построении движений. М.: Изд-во АПН, 1947. 255 с.

5. Бернштейн Н. А. Очерки физиологии движений и физиологии активности. М.: Изд-во АПН, 1966. $349 \mathrm{c}$.

6. Бехтерева Н. П. Нейрофизиологические аспекты психической деятельности человека. Л.: Наука, 1971. $120 \mathrm{c}$.

7. Бехтерева Н. П. Здоровый и больной мозг человека. Л.: Наука, 1980. 208 с.

8. Бианки В. Л. Эволюция парной функции мозговых полушарий. Л.: Наука, 1967. 260 с.

9. Бианки В. Л. Механизм парного мозга. Л.: Наука, 1989. 264 с.

10. Выготский Л. С. Развитие высших психических функций. М.: Педагогика, 1960.

11. Выготский Л. С. Избранные психологические исследования. М.: Педагогика, 1956. 519 с.

12. Гальперин П. Я. Развитие исследований по формированию умственных действий.

Психологическая наука в СССР. М.: Педагогика, 1959. 445 с.

13. Гальперин П. Я. Введение в психологию. М.: МГУ, 1976. 150 с.

14. Леонтьев А. Н. Проблемы развития психики. М.: МГУ, 1981. 854 с.

15. Леонтьев А. Н. Деятельность. Сознание. Личность. М.: МГУ, 1975. 304 с.

16. Лурия А. Р. О двух видах персевераций при поражениях лобных долей мозга. В кн.: Лобные доли и регуляция психических процессов. М.: МГУ, 1966.

17. Лурия А. Р. Основы нейропсихологии. М.: МГУ, 1973. 373 с. 
18. Лурия А. Р. Высшие корковые функции человека и их нарушение при локальных поражениях мозга. М.: МГУ, 1962. 433 с.

19. Лурия А. Р. Мозг человека и психические процессы. М.: Педагогика, 1963. Т. 1.

20. Лурия А. Р. Язык и сознание. М.: МГУ, 1979. 319 с.

21. Ломов Б. Ф. Методологические и теоретические проблемы психологии. М.: Наука, 1984. $445 \mathrm{c}$.

22. Корсакова Н. К., Микадзе Ю. В., Балашова Е. Ю. Неуспевающие дети: нейропсихологическая диагностика трудностей в обучении младших школьников. М.: Роспедагентство, 1997. 123 с.

23. Манелис Н. Г. Сравнительный нейропсихологический анализ формирования высших психических функций у здоровых детей и детей с аутическими расстройствами: Автореф. дисс. канд. психол. наук. М., 2000. 24 с.

24. Павлов И. П. Лекции о работе больших полушарий. Полное собрание трудов. 2-е доп. изд. М.: Наука, 1951. Т. 4. 592 с.

25. Петровский А. В., Ярошевский М. Г. История и теория психологи. Ростов-н/Д.: Феникс, 1996. $416 \mathrm{c}$.

26. Саркисов С. А. Очерки по структуре и функции мозга. М.: Медицина, 1964. 298 с.

27. Симерницкая Э. Г. Мозг человека и психические процессы в онтогенезе. М.: МГУ, 1985. $181 \mathrm{c}$.

28. Смирнов В. М. Стереотаксическая неврология. Л.: Медицина, 1976. 262 с.

29. Ухтомский А. А. Физиологическая лабильность и равновесие. Собр. соч. М.-Л.: Наука, 1966. T. 6. 272 c.

30. Ухтомский А. А. Доминанта. СПб.: Питер, 2002. 448 с.

31. Филимонов И. Н. Избранные труды. М.: Медицина, 1974. 340 с.

33. Фарбер Д. А., Бетелева Т. Г., Дубровинская Н. В., Мачинская Р. И. Нейрофизиологические основы динамической локализации функций в онтогенезе. I Международная конференция памяти А. Р. Лурия: Сб. докладов. Под ред. Е. Д. Хомской, Т. В. Ахутиной. М.: РПО, 1998. С. 208-215.

34. Хризман Т. П. Развитие функции детского мозга. Л.: Наука, 1978. 282 с.

35. Хомская Е.Д. Мозг и активация. М.: МГУ, 1983. 216 с.

36. Хомская Е.Д., Привалова Н. Н., Ениколопова Е. В. Методы оценки межполушарной асимметрии и межполушарного взаимодействия. М.: МГУ, 1995. 78 с.

37. Хомская Е. Д. Нейропсихология. М. : Питер, 2012. 496 с.

38. Функции лобных долей мезга. Под ред. Е. Д. Хомской, А. Р. Лурия. М.: Наука, 1982.

\section{References}

1. Adrianov O.S. Actual problems of the doctrine of the organization of brain functions / O.S. Andrianov // Methodological aspects of the science of the brain. M .: Nauka, 1983. $368 \mathrm{p}$.

2. Anokhin P. K. Biology and neurophysiology of the conditioned reflex / P. K. Anokhin. M.: Nauka, 1968.547 p.

3. Anokhin P. K. Essays on the physiology of functional systems / P. K. Anokhin. M .: Nauka, 1975. 447 p.

4. Bernshtein N. A. On the construction of movements / N. A. Bernshtein. M.: Publishing House of the APN, 1947. 255 p.

5. Bernstein N. A. Essays on the physiology of movements and the physiology of activity / N. A. Bernshtein. M.: Publishing House of the APN, 1966. 349 p.

6. Ankylosing spondylitis P. Neurophysiological aspects of human mental activity / N. P. Ankylosing spondylitis. L .: Nauka, 1971. 120 p. 
7. Ankylosing spondylitis P. Healthy and diseased human brain / N.P. Ankylosing spondylitis. L .: Nauka, 1980. 208 p.

8. Bianchi V. L. Evolution of the paired function of the cerebral hemispheres / V. L. Bianchi. L .: Nauka, 1967.260 p.

9. Bianchi Century L. The mechanism of the paired brain / Century. L. Bianchi. L .: Nauka, 1989 . $264 \mathrm{p}$.

10. Vygotsky L. S. Development of higher mental functions / L. S. Vygotsky. - M.: Pedagogy, 1960.

11. Vygotsky L. S. Selected psychological research / L. S. Vygotsky. M .: Pedagogy, 1956. 519 p.

12. Halperin P. Ya. Development of research on the formation of mental actions / P. Ya. Halperin //

Psychological science in the USSR. M.: Pedagogy, 1959. 445 p.

13. Halperin P. Ya. Introduction to Psychology / P. Ya. Halperin. - M.: Moscow State University, 1976.- $150 \mathrm{p}$.

14. Leontyev A. N. Problems of the development of the psyche / A. N. Leontyev. M.: Moscow State University, 1981. $854 \mathrm{p}$.

15. Leontiev A. N. Activity. Consciousness. Personality / A.N. Leontiev. M .: Moscow State University, $1975.304 \mathrm{p}$.

16. Luria A. R. About two types of perseveration in lesions of the frontal lobes of the brain / A. R. Luria // In the book: Frontal lobes and regulation of mental processes. M.: Moscow State University, 1966.

17. Luria A. R. Fundamentals of Neuropsychology / A. R. Luria. M.: Moscow State University, 1973. $373 \mathrm{p}$.

18. Luria A. R. Higher cortical functions of a person and their violation in local brain lesions / A. R. Luria. M.: Moscow State University, 1962.433 p.

19. Luria A. R. Human brain and mental processes / A. R. Luria. M.: Pedagogy, 1963. T. 1.

20. Luria A. R. Language and consciousness / A. R. Luria. - M.: Moscow State University, 1979. 319 p.

21. Lomov B. F. Methodological and theoretical problems of psychology / B. F. Lomov. M .: Nauka, 1984. 445 p.

22. Korsakova N. K. Unsuccessful children: neuropsychological diagnosis of difficulties in teaching primary school children / N. K. Korsakova, Yu. V. Mikadze, E. Yu. Balashova. M .: Rospedagentstvo, $1997.123 \mathrm{p}$.

23. Manelis N. G. Comparative neuropsychological analysis of the formation of higher mental functions in healthy children and children with autistic disorders: Abstract. diss. Cand. psychol. sciences. M., 2000.24 p.

24. Pavlov I.P. Lectures on the work of the cerebral hemispheres / I.P. Pavlov // Complete Works. 2nd add. ed. M .: Nauka, 1951. T. 4. 592 p.

25. Petrovsky A.V. History and theory of psychology / Petrovsky A.V., Yaroshevsky M.G. Rostovn / D .: Phoenix, 1996. 416 p.

26. Sarkisov S. A. Essays on the structure and function of the brain / S. A. Sarkisov. M.: Medicine, 1964.298 p.

27. Simernitskaya Г.. G. Human brain and mental processes in ontogenesis / Г.. G. Simenitskaya. M .: Moscow State University, $1985.181 \mathrm{p}$.

28. Smirnov V. M. Stereotactic neurology / V. M. Smirnov. L .: Medicine, 1976.262 p.

29. Ukhtomsky A. A. Physiological lability and balance / A. A. Ukhtomsky. - Sobr. Op. M.-L .: Nauka, 1966. T. 6.272 p.

30. Ukhtomsky A. A. Dominant [Text] / A. A. Ukhtomsky. St. Petersburg: Peter, 2002 . 448 p.

31. Filimonov I. N. Selected works / I. N. Filimonov. M .: Medicine, 1974. 340 p.

33. Neurophysiological foundations of dynamic localization of functions in ontogenesis / Farber D. A., Beteleva T. G., Dubrovinskaya N. V., Machinskaya R. I. // I International Conference in Memory of A. R. Luria: Sat. reports / Ed. E. D. Chomsky, T.V. Akhutina. M .: RPO, 1998 . S. 208215.

34. Khrizman T. P. Development of the function of the children's brain / T. P. Khrizman. - L .: Nauka, 1978.- 282 p. 
35. Chomskaya E.D. Brain and activation / E. D. Chomskaya. M.: Moscow State University, 1983. $216 \mathrm{p}$.

36. Methods for assessing interhemispheric asymmetry and interhemispheric interaction / Chomskaya E.D., Privalova N.N., Enikolopova E.V. et al. - M.: Moscow State University, 1995. 78 p.

37. Chomskaya E. D. Neuropsychology / E. D. Chomskaya. M.: Peter, 2012 . 496 p.

38. Functions of the frontal lobes of the brain / Ed. E. D. Chomsky, A. R. Luria. M.: Science, 1982. 